\title{
Association of MHC Class I chain-related A (MIC-A) gene polymorphism with Type I diabetes
}

\author{
G. Gambelunghe $^{1}$, M. Ghaderi ${ }^{1}$, A. Cosentino ${ }^{2}$, Ad. Falorni ${ }^{3}$, P. Brunetti ${ }^{2}$, Al. Falorni ${ }^{2}$, C. B. Sanjeevi ${ }^{1}$ \\ ${ }^{1}$ Department of Molecular Medicine, Karolinska Institute, Stockholm, Sweden \\ ${ }^{2}$ Department of Internal Medicine and Endocrine and Metabolic Sciences, University of Perugia, Italy \\ ${ }^{3}$ Department of Gynaecology, Obstetrics and Paediatric Sciences, University of Perugia, Italy
}

\section{Abstract}

Aims/hypothesis. A distinct family of MHC genes has been identified in the class III region and denominated MHC Class I chain-related genes (MIC). The $M I C-A$ gene is located between the TNFA and the $H L A-B$ genes. The aim of our study was to test the association of the polymorphism of the $M I C$ - $A$ gene with Type I (insulin-dependent) diabetes mellitus and evaluate the interaction between $M I C-A$ and $T N F A, H L A-B, H L A-D R$ and $H L A-D Q$ gene polymorphism.

Methods. Type I diabetic $(n=95)$ and healthy $(n=98)$ Italian subjects were typed for exon 5 of $M I C-A$ and for $H L A-D R B 1, H L A-D Q A 1, H L A-$ $D Q B 1$ and TNFA alleles. All subjects were also typed for the presence of $H L A-B 8$ or $H L A-B 15$.

Results. The frequency of $M I C-A 5$ was increased in diabetic subjects $(53 \%$ vs $15 \%)(\mathrm{OR}=6.1)$ (corrected $\left.p, p_{c}<0.0005\right)$. Among HLA class II haplotypes, both HLA-DRB1*03-DQA1*0501-DQB1*0201 (DR3$D Q 2)$ and DRB1*04-DQA1*0301-DQB1*0302 (DR4-DQ8) ("at-risk class II haplotypes") were positively associated with diabetes $(\mathrm{OR}=6.7$ and 6.0, respectively) $\left(p_{c}<0.003\right)$. Also HLA-B8 was more frequent among Type I diabetic subjects than among healthy control subjects $(\mathrm{OR}=2.8, p=0.01)$. None of the TNFA alleles were statistically significantly associated with Type I diabetes. The $M I C$ - $A 5$ exon was negatively associated with age at clinical onset of diabetes $(p=0.012)$. Thus, $68 \%$ diabetic subjects younger than 25 years and $29 \%$ older than 25 years were carrying this allele. Both $M I C$ - $A 5$ and the at-risk class II haplotypes were independently associated with Type I diabetes and the combined association of the two markers had the highest relative risk $(\mathrm{OR}=172)$. In subjects younger than 25 years, the OR of $M I C-A 5$ was as high as 21.7 and was more than twofold that of at-risk class II haplotypes $(\mathrm{OR}=9.5)$. The $M I C-A 5$ exon was not in linkage disequilibrium with any of the HLA-class I, class II or TNFA alleles studied.

Conclusions/interpretation. The MIC-A gene polymorphism is associated with genetic risk for Type I diabetes and the combination of $M I C-A 5$ and at-risk class II haplotypes is now to be seen as the strongest genetic marker for this disease. [Diabetologia (2000) 43: 507-514]

Keywords Autoimmunity, genetic risk, HLA, insulindependent diabetes, major histocompatibility complex, TNFA gene.
Received: 6 September 1999 and in revised form: 30 December 1999

Corresponding author: C.B. Sanjeevi, MD, PhD, Molecular Immunogenetics Group, Department of Molecular Medicine, Karolinska Hospital, CMM, L8:03, S-171 76, Stockholm, Sweden

Abbreviations: MIC, Class I chain-related gene; GCT, trinucleotide repeat; ICA, islet cell antibodies; IA-2, tyrosine phosphatase; $\mathrm{OR}$, odds ratio; $p_{c}$, corrected $p$ value.
Type I (insulin-dependent) diabetes mellitus is an autoimmune disease characterised by the presence of circulating islet autoantibodies and by T-lymphocyte infiltration of the islets of Langerhans with consequent destruction of pancreatic beta cells [1]. A permissive genetic background is required for the development of the islet autoimmune process. Type I diabetes is a complex genetic disease and a long series of genes has been found to be linked with disease 
risk [2-12]. More specifically, the human leucocyte antigens (HLA) B8 [13] and B15 [14] increase the risk for Type I diabetes. The strongest genetic association so far identified, however, is with HLA class II genes located on the short arm of chromsome 6 . It is well known that both HLA DRB1*04DQA1*0301-DQB1*0302 (DR4-DQ8) and DRB1*03-DQA1*0501-DQB1*0201 (DR3-DQ2) (referred to as "at-risk class II haplotypes") are positively, and DRB1*15-DQA1*0102-DQB1*0602 is negatively, associated with Type I diabetes in the Caucasian population $[2,3,15,16]$. The relative risk of the DQA1*0501-DQB1*0201/DQA1*0301DQB1*0302 genotype is higher than 20 [17]. Only a minority of the subjects carrying the high risk haplotypes/genotypes develops the disease, however, which suggests that additional genes (as well as environmental factors) play a crucial part in conferring either protection or susceptibility to Type I diabetes.

The TNFA gene is located within the HLA class III region and its polymorphism influences the concentrations of TNF alpha produced [18]. In some studies, heterozigosity for $T N F A-2$ seems to increase the risk for Type I diabetes in subjects positive for DQA1*0501-DQB1*0201/DQA1*0301-DQB1*0302 [19]. The association of the TNFA gene polymorphism with Type I diabetes seems, however, to be due to a linkage disequilibrium with HLA class II genes $[19,20]$.

A distinct family of MHC genes has recently been identified within the class III region and has been denominated MHC class I chain-related genes (MIC) $[21,22]$. The MIC family consists of three pseudogenes, $M I C-C, M I C-D$ and $M I C-E$ and two functional genes, $M I C-A$ and $M I C-B$ [22]. The $M I C-A$ and $M I C-B$ genes are located telomeric to the TNFA gene between the $\mathrm{B}$-associated transcript $(B A T-1)$ and the $H L A-B$ genes [21-23]. The $M I C-A$ and $M I C-B$ genes contain long open reading frames encoding for MHC class I molecules with three distinct extracellular domains (alpha 1,2 and 3), a transmembrane segment, and a cytoplasmatic tail, each encoded by a separate exon. Sequence analysis of the $M I C-A$ gene showed a trinucleotide repeat (GCT) microsatellite polymorphism within the transmembrane region [24, 25]. So far, five alleles of the exon 5 of the $M I C$ - $A$ gene, which consist of 4, 5, 6 and 9 repetitions of GCT, or five repetitions of $G C T$ with an additional nucleotide insertion $(G G C T)$, have been identified [24]. These alleles have been accordingly named $A 4, A 5, A 6, A 9$ and $A 5.1$ and the sizes are, respectively, $179 \mathrm{bp}, 182 \mathrm{bp}, 185 \mathrm{bp}, 194 \mathrm{bp}$ and $183 \mathrm{bp}$.

The polymorphism of the $M I C$ - $A$ gene [24-26] and its location in the HLA region warrant studies aimed at identifying an association with the risk for autoimmune diseases. The $M I C$ - $A$ gene has already been found to confer genetic risk for Behçet's disease [27, 28] and ankylosing spondylitis [29]. We have recently shown additionally that the $M I C-A 5.1$ allele is statistically significantly increased in patients with autoimmune Addison's disease and that this association is not due to a linkage disequilibrium with HLA class II genes [30].

In this study, we evaluated the frequencies of $M I C$ $A$ alleles and genotypes in Italian Type I diabetic and healthy subjects and we tested the interaction between $M I C-A$ and TNFA, HLA-B, HLA-DR and $H L A-D Q$ gene polymorphism.

\section{Materials and methods}

Subjects and samples. Genomic DNA was obtained from EDTA-treated peripheral blood samples from 95 Type I diabetic subjects (age at onset 1-37 years, median 25 years; 40 females and 55 males) and 98 healthy subjects (age 3-64 years, median 33 years; 48 females and 50 males) resident in central Italy. The DNA samples were purified by standard phenolchloroform extraction, dissolved in sterile double-distilled water and stored at $4{ }^{\circ} \mathrm{C}$. Diagnosis of diabetes was made according to the criteria defined by the National Diabetes Data Group [31], and classification as Type I diabetes was based on the presence of ketosis, low body mass index and need for insulin therapy. In $93 \%$ of the subjects, the diagnosis of Type I diabetes was also confirmed by the presence of at least one of the three major islet autoantibodies: antibodies to islet-cell (ICA), GAD65 and tyrosine phosphatase-like molecules ICA512 (IA2). None of the healthy control subjects enrolled in this study was positive for islet autoantibodies.

Neither the patients nor the healthy control subjects were related to each other and no sib pairs were included in this study.

$M I C$ - $A$ genotyping. The exon 5 of the $M I C$ - $A$ gene was PCR amplified using 5 -CCTTTTTTTCAGGGAAAGTGC-3' as forward primer and $5^{\prime}$-CCTTACCATCTCCAGAAACTGC$3^{\prime}$ as reverse primer [24]. The reverse primer was labelled at 5 ' end with fluorescent reagent 6-HEX (Amersham-Pharmacia Biotech, Uppsala, Sweden). The reactions were done in a Perkin Elmer programmable thermal cycler (Perkin Elmer, Norwalk, Conn., USA). Following amplification, the number of the GCT triplet repeat units was determined using an ABI prism (Perkin Elmer) automated DNA sequencer.

$H L A$ class II genotyping. The polymorphic second exon of the $D Q A 1, D Q B 1$ and $D R B 1$ genes was amplified in a Perkin Elmer programmable thermal cycler and the amplified products were manually dotted onto nylon membranes (Amersham, Arlington, Ill., USA), under denaturing conditions. The membranes were hybridised with sequence specific oligonucleotides (SSOs), 3' end labelled with [32]P-deoxy cytosine tri phosphate (dCTP) and washed in stringent conditions before exposure to $\mathrm{x}$-ray film, as described previously [32]. The membranes were stripped of the labelled probe under alkaline conditions and reused for probing with other oligonucleotides.

$H L A-B 8$ and HLA-B15 genotyping. Because Type I diabetes is associated with $H L A-B 8$ and $H L A-B 15$, typing for these two alleles was done by PCR-SSP technique as described previously [33]. As positive controls, we used genomic DNA samples from four healthy subjects, identified as either B8-positive or $B 15$-positive by low-resolution typing method (Biotest, Drei- 
Table 1. MIC-A alleles and genotypes in Italian Type I diabetic and healthy subjects

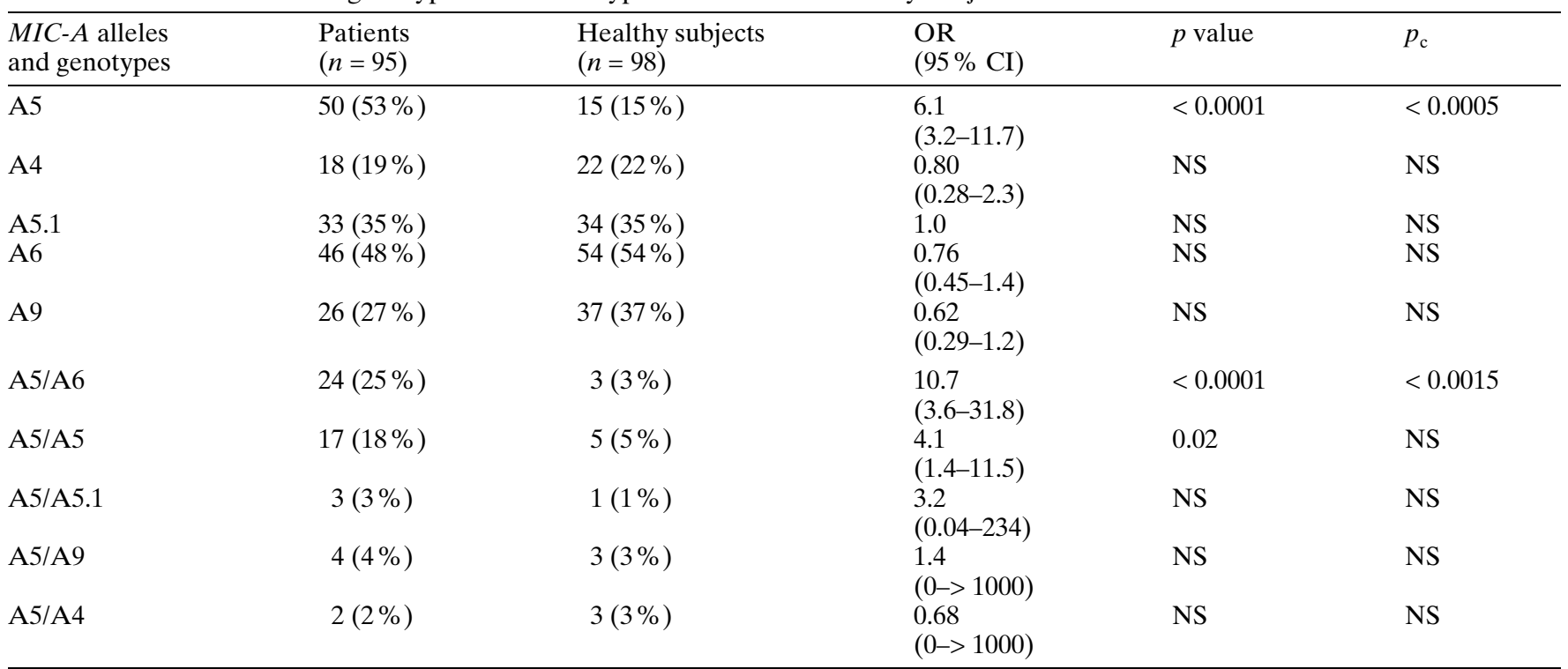

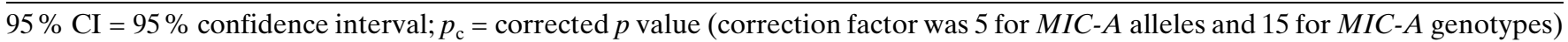

eich, Germany). Each PCR test included an internal positive control primer pair amplifying a segment of the human growth hormone gene.

TNFA microsatellite typing. Amplification by PCR of the TNFA gene was done as described [34]. The $5^{\prime}$ primer was labelled with HEX fluorescent dye. Fragment sizes were identified in an ABI prism automated DNA sequencer. According to the fragment size, 13 alleles of the TNFA gene have been identified [34].

Statistical analysis. The odds ratio (OR) was calculated as described previously $[35,36]$. When all the patients or the control subjects were negative for a particular allele or haplotype, Haldane's correction was used [37]. Differences in allele or haplotype frequencies between the diabetic subjects and the control group were tested by the chi-squared method. Yates' correction or the Fisher's exact tests were used when necessary. The strongest HLA association was tested using a method described previously [38]. The probability values were corrected $\left(p_{c}\right)$ for the number of comparisons, according to the number of alleles, haplotypes or genotypes observed among healthy subjects: 5 for $M I C$ - $A$ alleles, 15 for $M I C$ - $A$ genotypes, 26 for $H L A-D Q A 1-D Q B 1-D R B 1$ haplotypes and 13 for TNFA alleles. The probability value for $B 8$ and $B 15$ was not corrected, as they were the only $H L A-B$ alleles tested in our study. The dependency of the frequency of $M I C-A$ or $H L A-D R$ and $H L A-D Q$ alleles on sex and age at onset was assessed by logistic regression analysis. A $p$ (or $p_{c}$ ) value less than 0.05 was considered significant.

\section{Results}

The frequency of the MIC-A5 allele was increased in our cohort of Italian Type I diabetic subjects compared with the healthy control subjects and this allele had an OR of 6.1 (95\% CI: 3.2-11.7) $\left(p_{c}<0.0005\right)$ (Table 1). None of the other MIC-A al- leles was found to be associated, either positively or negatively, with the risk for the disease. Among the $M I C-A$ genotypes, only A5/A6 and A5/A5 were significantly and positively associated with Type I diabetes.

Among $H L A-D R$ and $D Q$ haplotypes, the risk for Type I diabetes was significantly associated with both DRB1*03-DQA1*0501-DQB1*0201 (DR3-DQ2) and DRB1*04-DQA1*0301-DQB1*0302 (DR4$D Q 8)$ (Table 2) $\left(p_{c}<0.003\right)$. The odds ratios of DR3-DQ2 (6.7, $95 \%$ CI: 3.4-13.3) and of DR4-DQ8 (6.0, 95\% CI: 2.6-13.9) were similar to that observed for MIC-A5. The DR3-DQ2/DR4-DQ8 genotype was absent in the 98 healthy control subjects but present in 11 of $95(12 \%)$ diabetic subjects (OR > 14.0, $95 \%$ CI: $2.7-70.2)$.

We found $H L A-B 8$ was more frequent among Type I diabetic subjects than among healthy control subjects (Table 2) $(\mathrm{OR}=2.8 p=0.01)$. The frequency of $B 15$ was slightly increased also in the diabetic cohort but the difference from the healthy control subjects was not statistically significant.

In our cohort of Type I diabetic and healthy subjects, no TNFA allele was positively or negatively associated with disease risk (Table 2). Although TNFA-2 was more frequent in diabetic subjects $(40 \%)$ than in healthy control subjects $(32 \%)$, the difference did not reach a statistical significance. Similarly, the presence of TNFA-2 did not increase the OR for Type I diabetes in either HLA-DR3- or $H L A-D R 4$-positive subjects. The absence of DR3$D Q 2 / D R 4-D Q 8$-positive subjects in our group of healthy control subjects did not allow us to test the hypothesis that TNFA-2 was increased in diabetic subjects carrying this genotype. 
Table 2. HLA class I and class II and TNFA gene polymorphism in Italian Type I diabetic and healthy subjects

\begin{tabular}{|c|c|c|c|c|c|}
\hline & $\begin{array}{l}\text { Patients } \\
(n=95)\end{array}$ & $\begin{array}{l}\text { Controls } \\
(n=98)\end{array}$ & $\begin{array}{l}\text { OR } \\
(95 \% \mathrm{CI})\end{array}$ & $p$ value & $p_{\mathrm{c}}$ \\
\hline$D R 3-D Q 2$ & $48(51 \%)$ & $13(13 \%)$ & $\begin{array}{l}6.7 \\
(3.4-13.3)\end{array}$ & $<0.0001$ & $<0.0026$ \\
\hline$D R 4-D Q 8$ & $30(32 \%)$ & $7(7 \%)$ & $\begin{array}{l}6.0 \\
(2.6-13.9)\end{array}$ & $<0.0001$ & $<0.0026$ \\
\hline $\begin{array}{l}D R 3-D Q 2 / D R 4-D Q 8 \\
\text { Genotype }\end{array}$ & $11(12 \%)$ & 0 & $\begin{array}{l}>14.0 \\
(2.7-70.2)\end{array}$ & 0.001 & 0.026 \\
\hline$B 8$ & $25(26 \%)$ & $11(11 \%)$ & $\begin{array}{l}2.8 \\
(1.2-6.3)\end{array}$ & 0.01 & 0.01 \\
\hline B15 & $14(15 \%)$ & $10(10 \%)$ & $\begin{array}{l}1.5 \\
(0.5-4.4)\end{array}$ & NS & NS \\
\hline TNFA1 & $8(8 \%)$ & $3(3 \%)$ & $\begin{array}{l}2.9 \\
(0.6-14.5)\end{array}$ & NS & NS \\
\hline TNFA2 & $38(40 \%)$ & $31(32 \%)$ & $\begin{array}{l}1.3 \\
(0.8-2.1)\end{array}$ & NS & NS \\
\hline TNFA3 & $5(5 \%)$ & $1(1 \%)$ & $\begin{array}{l}5.3 \\
(0.41-68)\end{array}$ & NS & NS \\
\hline TNFA4 & $11(11 \%)$ & $12(13 \%)$ & $\begin{array}{l}0.94 \\
(0.11-7)\end{array}$ & NS & NS \\
\hline TNFA5 & $20(21 \%)$ & $14(14 \%)$ & $\begin{array}{l}1.6 \\
(0.66-3.9)\end{array}$ & NS & NS \\
\hline TNFA6 & $14(15 \%)$ & $21(21 \%)$ & $\begin{array}{l}0.63 \\
(0.22-1.6)\end{array}$ & NS & NS \\
\hline TNFA7 & $22(23 \%)$ & $23(23 \%)$ & 1.0 & NS & NS \\
\hline TNFA8 & $1(1 \%)$ & $5(5 \%)$ & $\begin{array}{l}0.20 \\
(0.01-2.7)\end{array}$ & NS & NS \\
\hline TNFA9 & $1(1 \%)$ & $8(8 \%)$ & $\begin{array}{l}0.12 \\
(0.01-0.95)\end{array}$ & 0.04 & NS \\
\hline TNFA10 & $36(38 \%)$ & $40(41 \%)$ & $\begin{array}{l}0.88 \\
(0.61-1.3)\end{array}$ & NS & NS \\
\hline TNFA11 & $10(10 \%)$ & $9(9 \%)$ & $\begin{array}{l}1.1 \\
(0.07-15.9)\end{array}$ & NS & NS \\
\hline TNFA12 & $1(1 \%)$ & $2(2 \%)$ & $\begin{array}{l}0.51 \\
(0->100)\end{array}$ & NS & NS \\
\hline TNFA13 & $4(4 \%)$ & $11(11 \%)$ & $\begin{array}{l}0.35 \\
(0.06-1.4)\end{array}$ & NS & NS \\
\hline
\end{tabular}

$95 \% \mathrm{CI}=95 \%$ confidence interval; $p_{\mathrm{c}}=$ corrected $p$ value (correction factor was 13 for TNFA alleles and 26 for HLA haplotypes/ genotypes)

The logistic regression analysis showed that the frequency of the $M I C-A 5$ allele in diabetic subjects, but not that of either $D R 3-D Q 2$ or $D R 4-D Q 8$, was dependent on age at onset of diabetes $(p=0.012)$, but did not depend on sex. Thus, 39 of 57 (68\%) patients younger than 25 years were positive for the $M I C$ - $A 5$ allele, as compared with 11 of 38 (29\%) patients older than 25 years (Fig. 1). In Type I diabetic subjects older than 25 years, the frequency of $M I C$ $A 5$ (11 of $38,29 \%)$ was not significantly higher than the frequency observed in healthy subjects with similar age $(18 \%)$.

To evaluate whether $M I C-A 5$ is independently associated with Type I diabetes, we then did the test for the strongest HLA association using a method described previously [38] (Tables 3, 4). This analysis confirmed that both $M I C-A 5$ and $H L A$ DR3-DQ2 and/or HLA DR4-DQ8 were independently associated with Type I diabetes (Table 4 comparisons 1, 2, 3, 4, 5 and 6) and showed that the combined association of $M I C-A 5$ and at-risk HLA class II haplotypes was associated with the highest odds ratio (Table 4, comparison 8). No linkage disequilibrium between $M I C$ $A$ and HLA class II genes was detected in either patients or healthy control subjects (Table 4, comparisons 9 and 10). Similarly, the polymorphism of the $M I C$ - $A$ gene did not result in linkage disequilibrium with that of the TNFA gene.

These results show that $M I C-A 5$ is associated with Type I diabetes and that $M I C-A$ and $H L A$ $D R-D Q$ polymorphism interact in conferring genetic risk for the disease. When the analysis was repeated in subjects younger than 25 years, the presence of MIC-A5 had an OR of 21.7 (95\% CI: 7.9-59.9) $\left(p_{c}<0.0005\right.$ vs healthy subjects of similar age), which was more than twofold that associated with the presence of at-risk class II haplotypes $(\mathrm{OR}=9.5$, 95\% CI: 3.9-23.4). In the same group of patients, the relative risk of the simultaneous presence of both $M I C-A 5$ and $D R 3-D Q 2$ and/or DR4$D Q 8$ was 775 -fold that associated with the absence of both markers. 

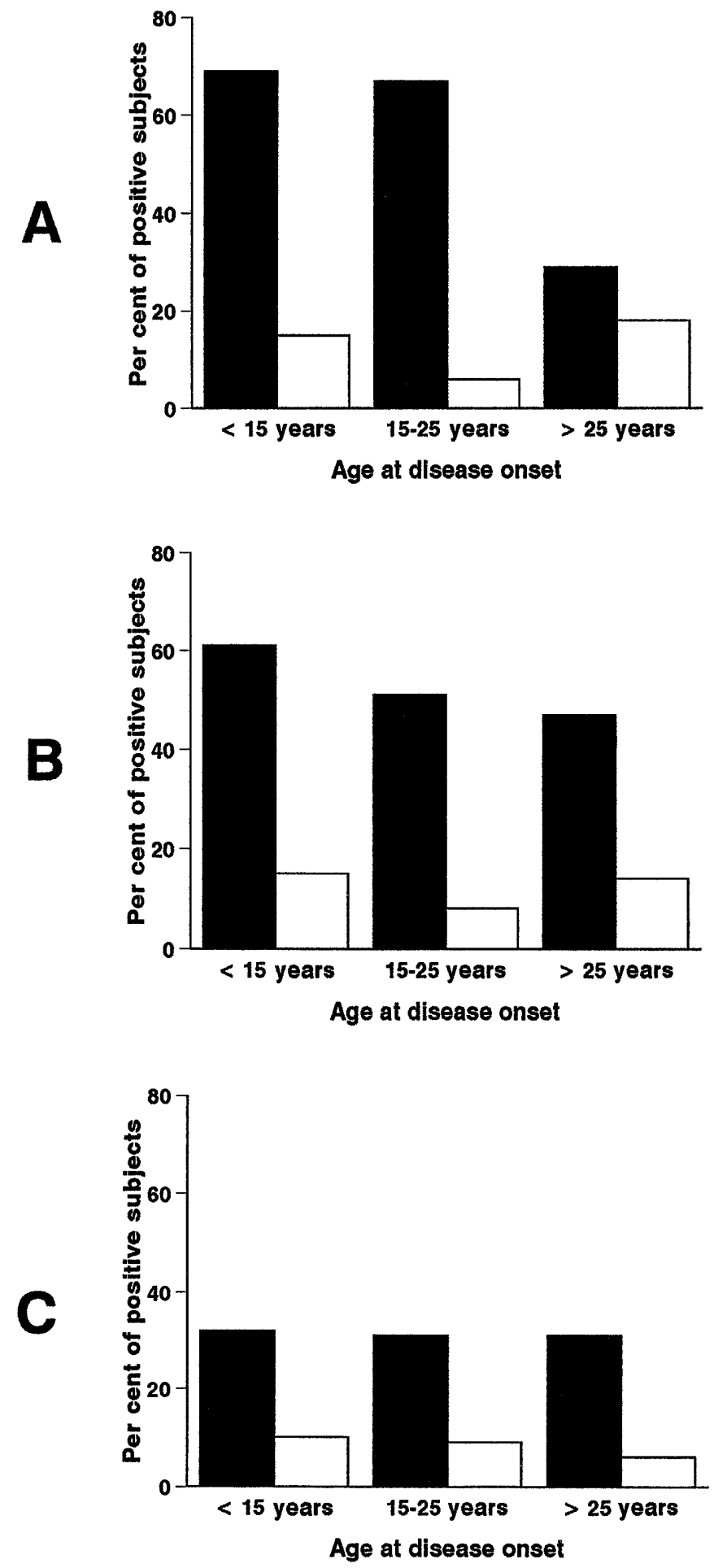

Fig.1A-C. Frequency of $M I C-A 5$ (A), HLA-DRB1*03DQA1*0501-DQB1*0201 (DR3-DQ2) (B) and HLADRB1*04-DQA1*0301-DQB1*0302 (DR4-DQ8) (C) in Italian Type I diabetic subjects, in relation to age at disease onset and in age-matched healthy control subjects. $\square$, Type I diabetic subjects; $\square$, healthy control subjects
Table 3. Analysis of the strongest HLA association comparing $M I C$ - $A 5$ with $D R 3-D Q 2$ and/or $D R 4-D Q 8$. Basic data

\begin{tabular}{llll}
\hline $\begin{array}{l}\text { Factor A } \\
(M I C-A 5)\end{array}$ & $\begin{array}{l}\text { Factor B } \\
(\text { HLA DR3-DQ2 } \\
\text { and/or DR4-DQ8) }\end{array}$ & $\begin{array}{l}\text { Patients } \\
(n=95)\end{array}$ & $\begin{array}{l}\text { Healthy subjects } \\
(n=98)\end{array}$ \\
\hline+ & + & $35(\mathrm{x} 1)$ & $1(\mathrm{y} 1)$ \\
+ & - & $15(\mathrm{x} 2)$ & $14(\mathrm{y} 2)$ \\
- & + & $32(\mathrm{x} 3)$ & $19(\mathrm{y} 3)$ \\
- & - & $13(\mathrm{x} 4)$ & $64(\mathrm{y} 4)$ \\
\hline
\end{tabular}

$\mathrm{x}, \mathrm{y}=$ reference alphabet for identification of healthy subjects

Furthermore, the test for the strongest HLA association also showed the absence of linkage disequilibrium between $M I C-A 5$ and $H L A-B 8$ and that $M I C$ $A 5$ and $B 8$ are independently associated with Type I diabetes $(\mathrm{OR}=6.4$ for $M I C-A 5$ in the absence of $\left.H L A-B 8, p_{c}<0.0006\right)$. Similarly, the association between $M I C-A 5$ and the risk for Type I diabetes was not influenced by the presence of $H L A-B 15$.

\section{Discussion}

Our study shows that $M I C$ - $A$ gene polymorphism is associated with the risk for Type I diabetes. In our cohort of Italian subjects, the genetic susceptibility to the disease was best represented by the interaction between HLA-DR3-DQ2 and/or HLA-DR4-DQ8 and $M I C-A 5$ and did not depend on TNFA gene polymorphism. The $M I C$ - $A 5$ exon seems to be the strongest genetic marker of susceptibility to Type I diabetes in subjects younger than 25 years.

The function of the $M I C$ - $A$ gene product is little understood. Furthermore, it is still not clear how the gene polymorphism could influence the biological importance of the MIC-A molecule. The crystal structure of the MIC-A molecule has been determined and showed a dramatically altered MHC class I fold [39]. More specifically, an unusual distribution of amino acid substitutions is present in the putative ligand-binding site of the MIC molecule [25]. The MHC class I homologue MIC-A is recognised by one subset of $\gamma \delta$ T-cells and could present invariant ligands such as glycolipids or carbohydrates [21, 25, 40]. The MIC-A protein is essentially expressed in the gut epithelium and no expression has been found in B-lymphocytes or T-lymphocytes [21, 41]. The expression of MIC-A is not under the control of the classical HLA molecules stimuli [21, 40] but under that of heat-shock promoter elements [41]. Its expression can be induced, however, in $\mathrm{CD}^{+}$and $\mathrm{CD}^{+}$ cells, by stimulation with phytohemoagglutinin [40]. These data suggest a putative role of MIC-A in inflammatory processes.

The existence of susceptibility genes for Type I diabetes within the segment of MHC between TNFA and $H L A-B$ genes had already been predicted [42]. 
Table 4. Test of the strongest HLA association comparing $M I C$ - $A 5$ with $D R 3-D Q 2$ and/or $D R 4-D Q 8$

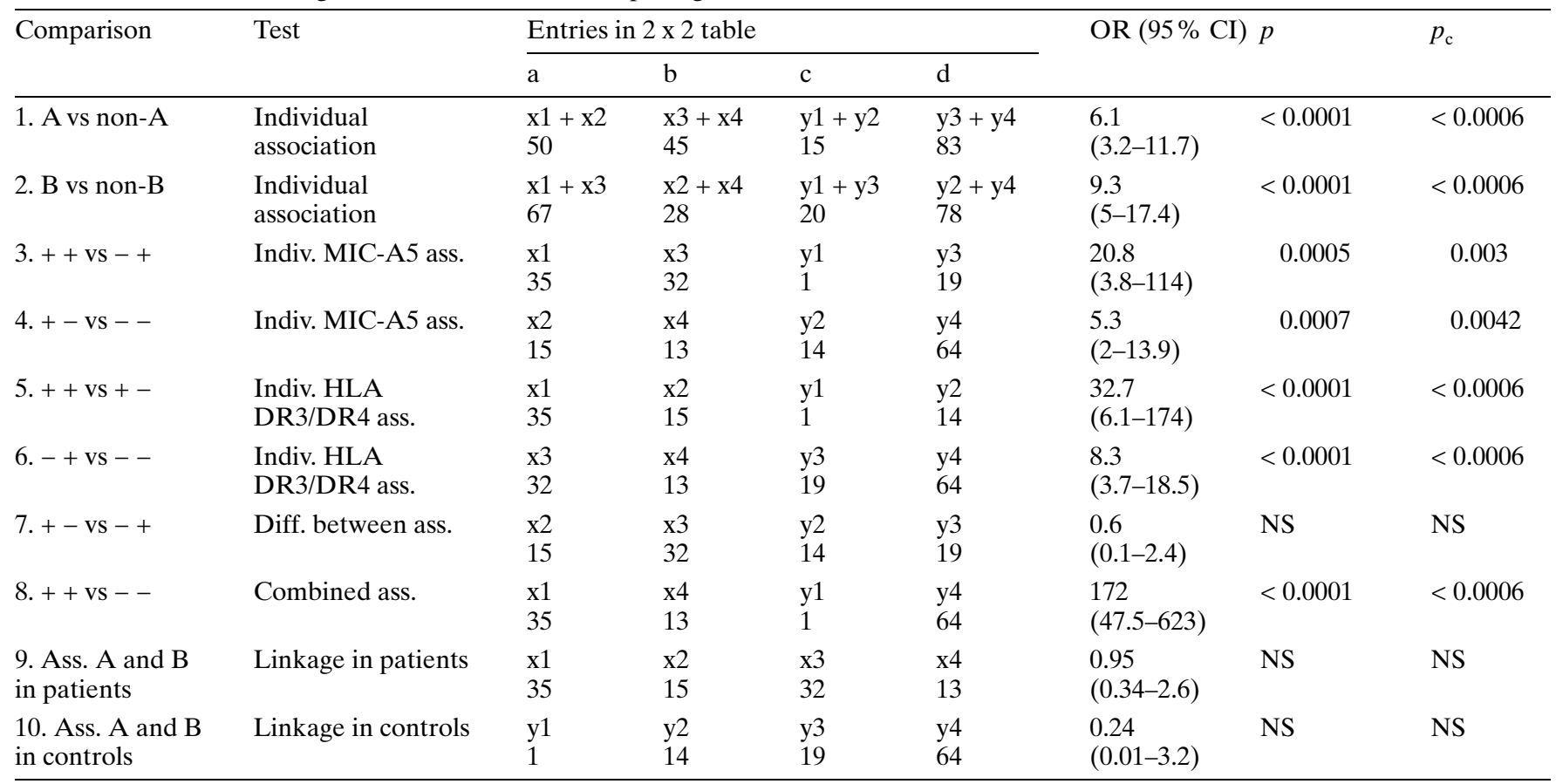

$95 \% \mathrm{CI}=95 \%$ confidence interval; $p_{\mathrm{c}}=$ corrected $p$ value (correction factor was 6 for comparisons $1-8$ and 9 for comparisons 9 and 10). ass. $=$ association, Indiv. $=$ individual, Diff. $=$ difference, $\mathrm{x}, \mathrm{y}=$ reference alphabet for identification of healthy subjects

Our study shows now that the polymorphism of the $M I C$ - $A$ gene, located in that MHC segment, indicates the genetic risk for Type I diabetes. This association could be the result of a linkage disequilibrium between the $M I C-A$ gene and a still unidentified gene in the HLA region. In this respect, the absence of linkage disequilibrium with HLA class II haplotypes and with $T N F A$ alleles is highly relevant. These results are in line with the absence of linkage disequilibrium between the $M I C$ - $A$ and the $M I C$ - $B$ genes [43, 44], that we have also confirmed in the Italian cohort [30], and this is presumably due to a recombination hot-spot between the two $M I C$ genes [45]. The results of our paper are thus consistent with the hypothesis that the association of $M I C-A$ polymorphism with Type I diabetes is not due to a linkage disequilibrium with genes located centromeric to the $M I C$ - $A$ gene, e. g. in the HLA class II and class III regions.

Some studies have tested the association of TNFA gene polymorphism with the risk for Type I diabetes [18-20]. The TNFA microsatellite alleles do not seem to be independently associated with the disease. Similarly, in our study, no TNFA allele was found to be statistically significantly increased in Type I diabetic subjects.

To evaluate whether the association of $M I C-A 5$ with Type I diabetes was influenced by $H L A-B$ gene polymorphism, we estimated the frequency of $B 8$ and $B 15$ in our cohort of Italian subjects. Our results on class I association are in line with those of previous studies on Italian diabetic subjects [46] and show that
$M I C-A 5$ is associated with the risk for Type I diabetes independently of $H L A-B$ gene polymorphism.

Several lines of evidence support the hypothesis that different immune and genetic associations distinguish childhood Type I diabetes from the adult form of the disease. Thus, insulin autoantibodies, IA-2/ ICA512Ab and ICA are less frequent in adult patients than in children [47-49] and $H L A-D R 4-D Q 8$ is strongly associated with childhood Type I diabetes [50]. These different associations are likely correlated with the different clinical manifestations of the disease, more acute and pronounced in children and often slowly progressive in adult subjects. The inverse correlation between the frequency of $M I C$ - $A 5$ and age at onset of the disease further supports the hypothesis that a distinct genetic background characterises childhood Type I diabetes. It is notable that APS II-Addison's disease, which is very rare in children, was found to be associated with $M I C-A 5.1$, and not with $M I C-A 5$ [30]. Further studies on adultonset, slowly progressive Type I diabetes, as well as on other organ-specific autoimmune diseases, are needed to address the question whether $M I C-A 5.1$ is a genetic marker of adult-onset endocrine autoimmunity, compared to $M I C-A 5$, which might result as a specific marker of childhood Type I diabetes.

Our study shows that $M I C-A$ gene polymorphism is strongly associated with risk for Type I diabetes. According to our data, the combination of MIC-A5 and $H L A-D R 3-D Q 2$ and/or $H L A-D R 4-D Q 8$ is now to be seen as the most important genetic marker iden- 
tified for this disease. The typing of the $M I C-A$ gene will be instrumental in the future identification of subjects at high risk for Type I diabetes and in the planning of intervention trials.

Acknowledgements. This study was supported by funds from the Swedish Medical Research Council, Karolinska Institute, Swedish Diabetes Association, Barn diabetes fund, Novo Nordisk Fund, Åke Wiberg Fund, Swedish Physicians Association to CBS and from the Juvenile Diabetes Foundation International to A. Falorni and from the University of Perugia ("Progetto Giovani Ricercatori", 1999) to G. Gambelunghe. The financial support of Telethon (grant E.C787) to A. Falorni is also gratefully acknowledged.

We wish to thank the following members of the Umbria Type I Diabetes Registry who collected blood samples from diabetic subjects: A. Angeli (Gubbio), E. Baiocchi (Assisi), D. Belladonna (Todi), R. Bellanti (Città di Castello), M. Bracaccia (Orvieto), C. Campanelli (Città di Castello), G. Campolo (Todi), G. Cicioni (Terni), S. Coaccioli (Terni), A. Coletti (Gualdo Tadino), M. Cozzari (Cascia), G. De Giorgi (Perugia), G. Di Matteo (Perugia), G. Divizia (Spoleto), G. Fracassi (Marsciano), A. Frascarelli (Assisi), S. Gagliardo (Narni), G. Giannico (Marsciano), A. Lilli (Gubbio), E. Madeo (Città della Pieve), G. Mancini (Orvieto), R. Marcacci (Castiglione del Lago), M. Napolitano (Foligno), G. Pennoni (Gualdo Tadino), E. Picchio (Perugia), S. Pocciati (Foligno), F. Santeusanio (Perugia), M. Scattoni (Narni), E. Vignai (Città della Pieve).

\section{References}

1. Lernmark $\AA$, Falorni A (1997) Immunology of insulin-dependent diabetes mellitus. In: Pickup J, Williams G (eds) Textbook of Diabetes. Blackwell Science, Oxford, pp 1-23

2. Sanjeevi CB, Kockum I, Lernmark ^ (1995) The role of major histocompatibility complex in insulin dependent diabetes mellitus. Curr Opin Endocrinol Diabetes 2: 3-11

3. Nepom GT (1993) Immunogenetics and IDDM. Diabetes Rev 1: 93-103

4. Davies JL, Kawaguchi Y, Bennett ST et al. (1994) A genome-wide search for human type 1 diabetes susceptibility genes. Nature 371: 130-136

5. Hashimoto L, Habita C, Beressi J et al. (1994) Genetic mapping of a susceptibility locus for insulin-dependent diabetes mellitus on chromosome 11q. Nature 371: 161-164

6. Field LL, Tobias R, Magnus T (1994) A locus on chromosome 15q26 (IDDM 3) produces susceptibility to insulindependent diabetes mellitus. Nat Genet 8: 189-194

7. Copeman JB, Cucca F, Herane CM et al. (1995) Linkage disequilibrium mapping of chromosome $6 \mathrm{q}$ in type 1 diabetes. Hum Mol Genet 5: 1071-1074

8. Owerbach D, Gabbay KH (1995) The HOXD8 locus (2q31) is linked to type 1 diabetes; interaction with chromosome 6 and 11 disease susceptibility genes. Diabetes 44: $132-136$

9. Luo DF, Maclaren NK, Huang HS, Muir A, She JX (1995) Intrafamilial and case-control association analysis of D2S152 in insulin-dependent diabetes. Autoimmunity 21: 143-147

10. Zamani M, Pociot F, Raeymaekers P, Nerup J, Cassiman JJ (1996) Linkage of type I diabetes to 15q26 (IDDM 3) in the Danish population. Hum Genet 98: 491-496

11. Nisticò L, Buzzetti R, Pritchard LE et al. (1996) The CTLA-4 gene region of chromosome 2q33 is linked to, and associated with, type 1 diabetes. Hum Mol Genet 5: 1075-1080

12. Esposito L, Hill NJ, Pritchard LE et al. (1998) Genetic analysis of chromosome 2 in Type 1 diabetes. Analysis of putative loci IDDM7, IDDM12, and IDDM13 and candidate genes NRAMP1 and IA-2 and the interleukin-1 gene cluster. Diabetes 47: 1797-1799

13. Nerup J, Platz P, Anderssen OO (1974) HL-A antigens and diabetes mellitus. Lancet ii: $864-866$

14. Singal DP, Blajchman MA (1973) Histocompatibility (HLA) antigens, lymphocytotoxic antibodies and tissue antibodies in patients with diabetes mellitus. Diabetes 22: 429-432

15. Ronningen KS, Sprukland A, Iwe T, Vartdal F, Thorsby E (1991) Distribution of HLA-DRB, DQA1 and -DQB1 alleles and DQA1-DQB1 genotypes among Norwegian patients with insulin-dependent diabetes mellitus. Tissue Antigens 37: 105-111

16. Sanjeevi CB, Lybrand TP, DeWeese C et al. (1995) Polymorphic amino acid variations in HLA-DQ are associated with systematic property changes and occurrence of insulin-dependent diabetes mellitus. Diabetes 44: 125-131

17. She JX (1996) Susceptibility to type I diabetes: HLA-DQ and DR revisited. Immunol Today 17: 329-336

18. Pociot F, Briant L, Jongeneel CV et al. (1993) Association of tumor necrosis factor (TNF) and class II major histocompatibility complex alleles with the secretion of TNF-alpha and TNF-beta by human mononuclear cells: a possible link to insulin-dependent diabetes mellitus. Eur J Immunol 23: 224-231

19. Moghaddam P, Zwinderman A, de Knijff P et al. (1997) TNFa microsatellite polymorphism modulates the risk of IDDM in Caucasians with the high-risk genotype HLA DQA1*0501-DQB1*0201/DQA1*0301-DQB1*0302. Belgian Diabetes Registry. Diabetes 46: 1514-1515

20. Monos DS, Kamoun M, Udalova IA et al. (1995) Genetic polymorphism of the human tumor necrosis factor region in insulin-dependent diabetes mellitus. Linkage disequilibrium of TNFab microsatellite alleles with HLA haplotypes. Hum Immunol 44: 70-79

21. Bahram S, Bresnahan M, Geraghty DE, Spies T (1994) A second lineage of mammalian major histocompatibility complex class I genes. Proc Natl Acad Sci USA 91: 6259-6263

22. Bahram S, Spies T (1996) The MIC gene family. Rev Immunol 147: 328-333

23. Bahram S, Spies T (1996) Nucleotide sequence of a human MHC class I MICB cDNA. Immunogenetics 43: 230233

24. Ota M, Katsuyama Y, Mizuki N et al. (1997) Trinucleotide repeat polymorphism within exon 5 of the MICA gene (MHC class I chain-related gene A): allele frequency data in the nine population groups Japanese, Northern Han, Hui, Uygur, Kazakhstan, Iranian, Saudi Arabian, Greek and Italian. Tissue Antigens 49: 448-454

25. Fodil N, Laloux L, Wanner V et al. (1996) Allelic repertoire of the human MHC class I MICA gene. Immunogenetics 44: $351-357$

26. Ricci Vitiani L, Potolicchio I, D'Amato M, Baricordi O, Sorrentino R (1998) MICA exon 5 microsatellite typing by DNA heteroduplex analysis: a new polymorphism in the transmembrane region. Tissue Antigens 51: 309-311

27. Mizuki N, Ota M, Kimura M et al. (1997) Trinucleotide repeat polymorphism in the transmembrane region of the MICA gene: a strong association of six GCT repetitions with Behçet's disease. Proc Natl Acad Sci USA 94: 1298-1303 
28. Mizuki N, Ohno S, Sato T et al. (1995) Microsatellite polymorphism located between the TNF and HLA-B genes in Behçet's disease. Hum Immunol 43: 129-135

29. Yabuki K, Ota M, Goto K et al. (1999) Triplet repeat polymorphism in the MICA gene in HLA-B27 positive and negative Caucasian patients with ankylosing spondylitis. Hum Immunol 60: 83-86

30. Gambelunghe G, Falorni A, Ghaderi M et al. (1999) Microsatellite polymorphism of the MHC class I chain related (MIC-A and MIC-B) genes marks the risk for autoimmune Addison's disease. J Clin Endocrinol Metab 84: 3701-3707

31. National Diabetes Data Group (1979) Classification and diagnosis of diabetes mellitus and other categories of glucose intolerance. Diabetes 28: 1039-1049

32. Sanjeevi CB, Seshiah V, Möller E, Olerup O (1992) Different genetic background for Type I diabetes and malnutrition related diabetes in South Indians. Diabetologia 35: 283-286

33. Bunce M, O’Neill CM, Barnardo MCN et al. (1995) Phototyping: comprehensive DNA typing for HLA-A, B, C, DRB1, DRB3, DRB4, DRB5 6 DQB1 by PCR with 144 primer mixes utilizing sequence-specific primers (PCRSSP). Tissue Antigens 46: 355-367

34. Nedospasov S, Udalova I, Kuprash D, Turetskaya R (1991) DNA sequence polymorphism at the human necrosis factor locus. J Immunol 147: 1053-1059

35. Woolf B (1955) On estimating the relation between blood group and disease. Ann Hum Genet 19: 251-253

36. Miettinen OS (1976) The estimability and estimation in case-referent studies. Am J Epidemiol 103: 226-235

37. Haldane S (1956) The estimation and significance of the logarithm of a ratio of frequencies. Ann Hum Genet. 20: 309-311

38. Svejgaard A, Ryder L (1994) HLA and disease associations: detecting the strongest association. Tissue Antigens 43: $18-27$

39. Li P, Willie ST, Bauer S, Morris DL, Spies T, Strong RK (1999) Crystal structure of the MHC class I homolog MICA, a $\gamma \delta$ T cell ligand. Immunity 10: 577-584

40. Zwirner N, Fernandez-Vina M, Statsny P (1998) MICA, a new polymorphic HLA-related antigen, is expressed main- ly by keratinocytes, endothelial cells, and monocytes. Immunogenetics 47: 139-148

41. Groh V, Steinle A, Bauer S, Spies T (1998) Recognition of stress-induced MHC molecules by intestinal epithelial gammadelta T cells. Science 279: 1737-1740

42. Degli-Esposti M, McCann V, Abraham L, Spies T, Christiansen F, Dawkins R (1992) Ancestral haplotypes reveal the role of the central $\mathrm{MHC}$ in the immunogenetics of IDDM. Immunogenetics 36: 345-356

43. Ando H, Mizuki N, Ota M et al. (1997) Allelic variants of the human MHC class I chain-related B gene (MICB). Immunogenetics 46: 499-508

44. Kimura T, Goto K, Yabuki K et al. (1998) Microsatellite polymorphism within the MICB gene among Japanese patients with Behçet's disease. Hum Immunol 59: 500-502

45. Shiina T, Tamiya G, Oka A et al. (1998) Nucleotide sequencing analysis of the 146-kilobase segment around the IkBL and MICA genes at the centromeric end of the HLA class I region. Genomics 47: 372-382

46. Illeni MT, Pellegris G, Del Guercio ML et al. (1977) HLA antigens in diabetic children. Diabetes 26: 870-873

47. Vardi P, Ziegler AG, Matthews JH et al. (1988) Concentration of insulin autoantibodies at onset of type I diabetes: inverse log-linear correlation with age. Diabetes Care 9: 736-739

48. Seissler J, de Sonnaville JJ, Morgenthaler NG et al. (1998) Immunological heterogeneity in Type I diabetes: presence of distinct autoantibody patterns in patients with acute onset and slowly progressive disease. Diabetologia 41: 891-897

49. Vandewalle CL, Falorni A, Svanholm S et al. (1995) High diagnostic sensitivity of glutamate decarboxylase autoantibodies in insulin-dependent diabetes mellitus with clinical onset between age 20 and 40 years. J Clin Endocrinol Metab 80: 846-851

50. Vandewalle CL, Decraene T, Schuit FC et al. (1993) Insulin autoantibodies and high titre islet cell antibodies are preferentially associated with the HLA-DQA1*0301DQB1*0302 haplotype at clinical onset of Type I (insulindependent) diabetes before age 10 years but not at onset between age 10 and 40 years. Diabetologia 36: 1155-1162 